\title{
Science Education and Maxakali Tradition: Constructing Relationships in Search of a Common World
}

\author{
Katia Pedroso Silveira1, Eduardo Fleury Mortimer², Ana Maria Rabelo Gomes ${ }^{2}$ \\ ${ }^{1}$ Colégio Técnico da Universidade Federal de Minas Gerais (COLTEC/UFMG), Belo Horizonte, Brazil \\ ${ }^{2}$ Faculdade de Educação da Universidade Federal de Minas Gerais (FaE/UFMG), Belo Horizonte, Brazil \\ Email:katitaps@fmg.br
}

How to cite this paper: Silveira, K. P., Mortimer, E. F., \& Gomes, A. M. R. (2017). Science Education and Maxakali Tradition: Constructing Relationships in Search of a Common World. Creative Education, 8, 1590-1606.

https://doi.org/10.4236/ce.2017.810109

Received: June 16, 2017

Accepted: August 7, 2017

Published: August 10, 2017

Copyright $\odot 2017$ by authors and Scientific Research Publishing Inc. This work is licensed under the Creative Commons Attribution International License (CC BY 4.0).

http://creativecommons.org/licenses/by/4.0/

\begin{abstract}
This article presents a reflection on Science Education in the context of indigenous teachers training program of Maxakali indigenous group-people from the Northeastern region of Minas Gerais, Brazil. An attempt is made to portray some concerns, reflections and investigations in search of a possible approach for Science Education for this context. The Maxakali preserve not only their language, but their chants, myths and an intense ritual life. Thus, life in the village is permeated by the relationship between the tikmũ'n-as they name themselves and their yãmĩy, the singing spirits who are their source of knowledge. This dive into the tikmũ'un universe and the reflections on a set of science classes that dealt with the Maxakali in a training course for indigenous teachers, made it possible to outline a proposal approach to Science Education. An approach permeated by a more symmetrical relationship between the two systems of knowledge. Science teaching and learning is an inventive practice or creative exercise in Wagnerian terms. It means thinking of science classrooms as a relational space that favors a double anthropological exercise, both of indigenous students in search of an understanding of a science, and of science teachers seeking a greater understanding of the Amerindian universe. Science education is a cosmopolitical practice, a space for building a common world, as Latour suggests. This form of teaching reveals itself as pluricultural, recognizing the differences between two forms of rationality, scientific and traditional Maxakali, but also respecting and welcoming other ways of existing and knowing.
\end{abstract}

\section{Keywords}

Science Education, Indigenous Education, Maxakali, Cosmopolitics, Reverse Anthropology 


\section{Introduction}

The Maxakali, an indigenous people living in the state of Minas Gerais, Brazil, have a long history of resistance struggle. Against all odds, they have preserved, to this day, their language, their songs and their rituals. Few of these indigenous people speak Portuguese fluently, and village life is permeated with the relationships they maintain with their spirit-songs, the yãminy, which are their great source of knowledge.

The Maxakali people call themselves tikmũ unn, an expression that means "we humans", not in the sense of species, but of "human person", of "people". This human condition is expressed through language, participation in rituals, wearing of clothing, props, paintings and specific objects, as well as knowledge of the group's mythical songs and narratives. Constantly groups of spirits visit the tikmũ ũn. They come from the forest and remain among humans for long periods in which the yãmĩyxop-sacred rituals - ritual cycles in which the interaction between the Maxakali and the yãmĩy materializes. In these encounters the yãmĩy sing and dance for the tikmũ ũn. Singing is the main source of this interaction. In retribution, the tikmũ ũn offer food to yãmĩy. Every Maxakali sings the songs brought by yãmĩy. This is the way these spirits teach them everything they need to know. All this knowledge is conveyed by the teaching of the shamans and inscribed in paintings, masks, choreographies and in the Mĩmãnãmtree trunk erected in the center of the village during periods of rituals, which are worked graphically following each ritual. Musical art, body painting, and dance require important and well-developed skills among the Maxakali.

The people have demonstrated a keen interest in schooling and in non-indigenous knowledge. Many of them have already participated in indigenous educator professional developing courses and today serve as teachers in their village's schools.

Distinctly from traditional knowledge, scientific knowledge is based on a set of models, ideas developed by scientists with the intention of interpreting nature. Thus, entities, such as atoms and electrons, genes and chromosomes, fields and fluxes, are examples of models that are related to each other, being elaborated and re-elaborated according to the capacity that they have or not of explaining new phenomena. In this process, science is becoming symbolically and socially negotiated (Driver et al., 1999: p. 32).

This form of construction is very characteristic of science and differentiated from the way in which knowledge is produced daily. For many authors, learning science implies learning about "the scientific ways of knowing" (Driver et al., 1999: p. 32). It involves initiating students "into the ideas and practices of the scientific community and making these ideas and practices meaningful at the individual level” (Driver et al., 1999: pp. 32-33). However, this is not a simple process. Precisely because it is a very particular construction and distinct from common sense, many students face difficulties in learning science. On the other hand, the Indians also have their own unique and diverse way of interpreting and interacting with the world. 
In this context, conceiving science education in the professional developing of indigenous instructors, especially Maxakali instructors, had been a great challenge, since we are dealing with another universe, with another mode of being and acting on the world, with other interests rather different from those of western society. These differences bring to the classroom some of the very particular aspects of this situation, which if disregarded, could hinder the relationship between teaching and learning. Thus, the central aim of this article is to seek an approach to a science education that provides a more horizontal relationship between scientific knowledge and traditional Maxakali knowledge.

The work on this article was developed firstly by participating in professional developing of indigenous teachers, began in 2006 when some chemistry classes in an indigenous educator course were held, as part of the Program for the Implementation of Indigenous Schools of Minas Gerais-PIEI. The State Secretary of Education of Minas Gerais-SEE/MG - developed this program in partnership with the Federal University of Minas Gerais-UFMG, the National Indian Foundation - FUNAI, and the State Forest Institute. The program's objective was the establishment and implementation of pluricultural indigenous schools, guaranteeing these communities the right to specificity, difference, bilingualism, and interculturality (Dutra et al., 2003: p. 76) as instated in the Brazilian Constitution (Brasil, 1988).

This project was the fruit of a long process of organization and struggle by various indigenous peoples, which sought recognition as Brazilian citizens and as unique peoples holding their own customs, traditions, culture, and religions. In this sense, they also struggled for the right to manage their own schools in terms of both administration and pedagogy, which led the SEE/MG to propose a Master Course in Teaching Fundamentals for indigenous teachers, a course only recognized as PIEI, in reference to a program that originated it. The class of students with whom the teacher worked was constituted by the Pataxó, Xakriabá, Krenak and Maxakali ethnicities, all from Minas Gerais. Sometime afterwards, in 2009, the teacher offered, for the first time, a subject in the Course for the Intercultural Professional Developing of Indigenous Educators-FIEI, through the Faculty of Education at UFMG.

In order to reach the aim of this article, we present in Section 2 a set of activities developed with Maxakali students in a context of FIEI chemistry classes and we have tried to show how the particular way of being in the world of these students emerge in our discussions and, furthermore, how this way is constantly present for each of them even when they are not clearly stated. On the other hand, we also sought to analyze the teacher's position and the way in which she approaches the scientific view and, consequently, the difficulties that arise during this exchange.

From these analyses, we propose in Section 3 a reflection on science teaching as a space for pluriculturality. A way of teaching science that effectively promotes the encounter between different forms of knowledge, traditional and scientific, and that fosters students' abilities to construct scientific concepts 
starting from their own forms of meaning. To do so, we use the ideas of the anthropologist Wagner (2010) about creative capacity or inventive exercise in a search that allows the connection between different ways of knowing and acting on the world. A search for a common world, as Latour (2004) suggests, a world where we recognize the symmetry between the different forms of rationalities without ever denying their differences.

\section{Relationships between Scientific and Traditional Knowledge in the Space of the Science Classroom}

The class "Fundamental Themes in Chemistry I" was administered in 2009 as part of the activities of the Indigenous Degree Course of UFMG-FIEI, to a group of three Maxakali students: a couple from Aldeia Verde Indigenous Land, and a student from Cachoeirinha Indigenous Land, both located in the Northeast of the state of Minas Gerais, Brazil.

This class had as its central theme material properties and chemical transformations. The teacher's major intention was to try to understand the meaning that the Maxakali students attribute to the term transformation in order to, based on that formulation, be able to help them form a concept of chemical transformation. In this regard, she began by proposing that they speak about the raising of fish and the cultivation of a garden, activities that they had just begun to develop in Aldeia Verde at the time. The growth process of living beings appeared a pertinent theme, since the Maxakali detain immense knowledge about the forest and, specifically, about its diverse species of animals. On the other hand, in the scientific conception, the development of any living thing is always associated with a series of chemical transformations.

As soon as the theme was proposed, they began to talk about a garden that they were growing and especially about the fish nursery that they were implementing. The teacher then decided to direct the conversation towards possible explanations as to the process of raising fish. She reminded that, in order to keep fish alive and growing, it is necessary to feed them, that is to say, it is necessary that the fish eat food in order to grow. In this context, an analogy with the development of a child was attempted. The students' attention was called to the fact that all children need to be fed to survive and grow. As such, fish, like children, eat and then grow. Then, a second question was made: why does this happen?

They explained that, for the Maxakali, bathing, the oxygen in air, the wind and sleep are the things that make a person grow, to which one of them added: $I$ don't know that this is true. Immediately, the teacher sought to make clear that the group were not seeking a singular truth, and that different forms of explanation, be they those of the Maxakali, or non-indigenous or those of other peoples, are all equally valid and help each person to solve their questions. It was not about searching to find truth or error, or even, a more or less important viewpoint, to which the teacher said: for me it is important to understand how you comprehend these things because this will help me explain better the ways in 
which the people learn/ how you learned. I will learn your way and you will learn my way $[\ldots]$. She then suggested that she would conduct an exercise to familiarize herself with Maxakali explanations, in hope that they would be interested in learning her explanation, that is, the scientific explanation. In that moment one of the students that, until then, had shown the most distance from the conversation, asserted: We will exchange experience.

We realize the significance of the student's change in demeanor during the course of the conversation. This relationship is what permeates the life of these people. A pursuit is always through the relationship-relationship in the sense of exchange, of reciprocity. There is real interest, on their part, in understanding the western world. It is necessary to better understand the non-indigenous logic, for the sake of survival and the defense of their rights. However, beyond all of this, the relationship is what moves the Maxakali universe and it is by means of it that they interact with the white people.

It was in this context that, in what followed, the same student began to explain the two rituals through which all Maxakali children pass, which are fundamental for their development and training as tikmũ unn. Just as it happens in all other Maxakali rituals, these are also marked by exchange: the yãmĩy—spirits—bring their songs and, at times, the fruit of their hunting and are rewarded with nourishment offered by the women.

In the first ritual, which they call innikka' ok (Maxakali, 2008: p. 64), an expression that can be translated as "strong body", after a negotiation conducted through a shaman, the spirits of puxổou-earthworm-come to the village covered in clay. The group that solicited the presence of the yãminy then offers them a meal. The women of the village bring food like fruit and bread that are gathered in the center of the yard. Following that, directed by the shaman, which accompanies all their movements, the yãmĩy choose the children that will participate in the ritual, each between four and five years old. Then, they cover the bodies of the children in clay. Each one of them is laid upon the ground and stretched by four yãmĩy, simultaneously, by their feet and by their hands as a means of making them grow. The children are then placed on their feet and a yãmĩy steps on their feet pulling their arms upwards until they are, once again, stretched. By the end, the spirits offer food to each of them. The food, when eaten, should also help to facilitate growth. The mother, who accompanies the children the entire time, helps to carry the food back home. Stretching children and feeding them are factors that help in their growth.

They explained that even small children "can only be stretched" till they are "grasped" by Tatabox-the spirit of the caterpillar, in reference to a second ritual, the initiation ritual of the Maxakali, which only slightly older boys, six or seven years old, participate. The chosen boys are taken to a kuxex-a house of worship-where there are introduced into the Maxakali masculine universe. There they stay for thirty days in the company of their fathers, the shaman, and the yãmĩy learning about various masculine roles like hunting, fishing, agriculture and making things, and primarily, learning the songs and secrets of the 
Maxakali. This is an incredibly important ritual for the community. It is based on this experience that the Maxakali boys proceed to participate in ritual masculine life. Until then, just as the women, they cannot enter the kuxex-house of worship - and can only circulate in the domestic sphere, the feminine dimension of society (Álvares, 2012: p. 86).

When they had finished the more detailed explanations about the two rituals, the teacher realized that it would be very difficult to find a relationship that would enable her to associate these ideas with the concept of chemical transformation. As such, she decided to return to the scientific principle that she had been asking them: but which of these things makes one grow? It was her intention to prompt a renewed discussion about the relationship between nutrition and growth, however, immediately they returned to the ritual, responding: earthworms of coursel one gets stretched [...]. She sought to redirect the conversations then to the idea of the growth of animals and plants, until they could conclude that all of them were alive, including humans, precisely because they consumed food to grow.

After this preliminary conversation, the teacher began the activities that had been prepared as to discuss some other scientific ideas with the group. She prefaced her purpose, explaining her intention to understand the way in which the Maxakali explain the occurrence of some natural events, and at the same time, present them with the way in which science explains these phenomena. It was then proposed that they could observe the behavior of a sample of water being heated, and she suggested that they could try to explain, one to another, how the Maxakali and how science would interpret that phenomenon. The teacher asked that they attentively observe the process, and when the first small bubble began to arise, she asked them: What are these bubbles made of?

When a sample of water is heated, the rising of little bubbles, formed primarily on the sides of the vessel, can be observed within a few minutes. From a scientific point of view, with heat, the air dissolved into water expands and produces these initial bubbles. Air is a gaseous mixture and, because of this, needs little energy to form into little bubbles that rise throughout the beginning of the heating. With time, the system absorbs more and more energy until the water itself begins to transform itself into vapor giving rise to the larger bubbles that characterize the process of boiling. Thus, water that was presented in the form of liquid now shifts its physical state, transforming itself into a gas. The teacher's intention, however, was to bring them to consider the presence of air dissolved in water.

Surprisingly, the response to the inquiry about what are the bubbles made of was initially expressed through a single word: temperature. The teacher became very intrigued by this response, since, based on her conception of temperature she could not comprehend the sense that the students were attributing to the word. It was in this context that began a long discussion searching for a larger understanding of the different conceptions. So, when she questioned them about what they were trying to say with the word temperature, they suggested that 
bubbles are provoked by heat and then the water boils. The teacher then asked: but, is the water already boiling? They affirmed that it still was not, it was almost, it would boil when the water began to agitate, when the larger bubble rise. Then, she insisted: What, then, are these bubbles?

Throughout the discussion, the students suggested that the bubbles were smoke, foam and oxygen. However, the idea of air was never entertained. It was then realized that at last the water had reached the boiling point, which directed attention to the large bubbles that now were in the center of the vessel. In this context, striving to understand what conception they might have about the boiling of water, the teacher asked them about the larger bubbles. They quickly suggested that it was vapor and smoke. They stated further that the volume of water within the vessel diminished because, with heat, it would gradually transform into vapor and disperse itself through the air.

Slowly, the students presented new arguments that also made clearer the general idea that they had defended in the first activity, with regards to the initial bubbles. At the start of heating, tiny bubbles of water vapor had formed. With the increase of temperature these bubbles grew until they began to burst and release the vapor (or smoke) to the air. The water was then transformed into vapor, which provoked the decrease in the volume of the liquid water in the vessel.

It is interesting to observe the joint effort that they made to help the teacher understand the point of view that they sustained. This became most evident when she asked them several times what the bubbles were and, during the various responses and arguments they presented, the students would look at each other, one of them would offer a light smile, and then they would talk in Maxakali. This conversation was clearly a negotiation about what and how to say such that the teacher would understand. It was only then that a student affirmed: It's water/it's not hot, yet it is/depending on the temperature it will releasel a little bit of smoke from inside will come out, a little bit will come out, it will increase already the temperature inside that will come out like it is.

On the other hand, it is also important to emphasize what is behind the teacher's own practices over the course of the interaction. Various researchers have demonstrated the importance of dialogue in the learning of science (Mortimer \& SCOTT, 2003b). The construction of scientific concepts is a process that requires the joint involvement of both student and teacher, not only interacting but also dialoguing, in the sense of bringing different points of view to discussion. To define a concept with abstract clarity and objectivity is not sufficient to guarantee comprehension. It is crucial not to confuse the definition of a concept with the process of building that concept (Mortimer \& Machado, 2003a: p. 6). The practice of developing concepts in the classroom and employing the definition as something that should be memorized and applied inhibits contestation from the students who never find space for their doubts and interpretations of new situations. Beyond this, it engenders, for the student, the idea that science is a readymade product, verified and definitive and not a practice in permanent construction and reconstruction. It is with this perspective that the teacher in 
question always strives to approach chemistry concepts in a contextual manner. Towards this purpose, she uses, for example, experiments, accounts from everyday life, data from researchers, etc., which the students are pushed to reflect on and explain. These suggestions are then debated in the classroom, in a way that favors concepts being collectively constructed. It is in this exchange of ideas raised for different students that such concepts will become operable.

However, while exercises that explore and generate explanations are incredibly important for the process of science education, as a teacher, she felt she could not disregard the larger objective of her role, which is to present and teach scientific principles. As Mortimer and Scott (2003b) suggest, it is this that generates the tension between what they call dialogical discourse and authoritative discourse. It is from this tension that knowledge can be constructed. During a class, the teacher promotes the participation of students who are invited to share and discuss their ideas. However, at a crucial moment, slowly, the teacher will abandon a dialogic discourse and assume an authoritative discourse, the discourse of science.

When the Maxakali students signaled that they wanted to talk about their cosmology and that they were ready to begin an exchange, the teacher strove to demonstrate her openness to listen to them, without perceiving the limits that she herself had imposed on their "relationship". As was stated earlier, there was, on her part, a true interest in learning about the Maxakali, in listening to what they had to say. However, such listening is demarcated, restricted, since the teacher's larger goal was always to teach science. The goal was to understand more about the logic of Maxakali thought, and then, starting from there, convey scientific principles. This is made very clear when she said: for me it is important to understand how you comprehend these things because this will help me explain better the form in which people learn/so that you learn. I will learn your way and you will learn my way [...].

No matter how much respect was shown to the Maxakali viewpoint or how much she would sincerely concern herself with not presenting science as a unique and veritable answer, somehow, this always permeated her actions. It couldn't be different; after all she was born and raised in a universe that has science as its solution. What's more, she is a science teacher and believes in science.

However, as a counterpoint to what was said they told me: we will share experience, in other words, clearly their intentions were very different. They sought to exchange and the teacher sought a way to teach science, to demonstrate solutions, our answers. This will become clear when we analyze her conduct throughout the class. During the conversation about the growth of living beings, for example, there was an implicit intention on the teacher's part to discuss the transformations that food undergoes in living organisms. However, they were interested in the exchange and were concerned the entire time with helping me to understand how the yãmĩy made children grow. In the end, after all the discussion about the two rituals, she could only think of returning to her objective 
and, as such, asked again: but which of these things makes a child grow? And still they insisted: earthworms of coursel one gets stretched [...].

It was then that the teacher decided to shift strategies and direct the conversation to growth, not of people but of animals, which brought them, finally, to establish the connection with maternal care and food. They then spoke about the growth of plants, about how a seed turned into a plant. Then it was concluded that everything that was alive, including us, need to feed themselves in order to live.

The lesson about boiling water highlighted, perhaps in an even more significant way, these discrepancies. Again, after the teacher made clear her intention to understand the Maxakali's explanations about the phenomenon while also demonstrating the scientific explanation, or in other words, once again opening the door to exchange, the students embraced the chance immediately. All the while, she could not tell herself that, in truth what she really wanted was not an exchange, but simply to present scientific answers.

They engaged with the activity right from the start. They followed the assembly of the equipment, they were concerned with knowing what the teacher was using to light the stove and they were fascinated with reading the thermometer. When the first bubbles began to rise in the pot, she asked them about what the bubbles were made of, they suggested that the bubbles could be the temperature, which warmed and then would boil when the water began to agitate. Each one of the questions carried two implicit intentions, the first was to bring them to reflect on the phenomenon and help them make explicit the ideas that they were elaborating, to explain them. The second was to lead them to a scientific explanation.

This is a strategy that the teacher commonly utilizes with students in other classes. Starting from a contextualization of principles, a problem is brought up. Subsequently, the students are invited to present solutions. The ideas raised are debated with each class and new questions arise, until, together, a scientific explanation is reached. The debate is conducted in a manner that assists the students in identifying problems that can invalidate each idea, till they encounter the most adequate response, that is to say, the scientific explanation. This is an interesting strategy in that it incites students to reflect on the problem, form an exercise to find solutions for this problem, and even search for elements to defend their ideas. In the end, the scientific concept in question is rendered as the fruit of a collective construction, which in general significantly contributes to their understanding.

However, this strategy does not work as well with the Maxakali, who, moreover, left the teacher immensely frustrated on that occasion. In review of the recordings, it was realized that such a strategy would have barely succeeded. At no time did they "join in the teacher's game". It was like playing the same game with two different sets of rules. She would ask question after question trying to bring them to reflect on their own idea and reevaluate them, and they would struggle, through every means available, to help her simply to understand the 
idea that they were defending. Their intention was never to change their idea, but rather, to present their own elaboration and listen to the teacher's.

This does not mean, by any measure, a suggestion that they cannot change their opinion about anything or that they cannot or do not want to think with scientific principles. What is trying to be said is that the rules that were presented by the teacher and those that they accepted, you will tell me how you think and I will tell you how I think, were different rules than what she effectively put into practice.

It was also in this context that, even after it became clear to the teacher that in the eyes of the students the bubbles were water vapor, she continued insisting on making them realize the presence of air through by other means. She even believed that perhaps they had begun to understand what was behind this whole movement, after the teacher revealed that the bubbles were, in a scientific view, made of air and not of water.

In this way, this readiness towards dialogue, to hear the other, is restricted hearing in so far as another's idea is never valid, and on the contrary, it becomes a means by which the other is brought to recognize and accept scientific knowledge. On the other hand, these two episodes involving discussions about the growth of living beings and the boiling of water highlights relationships as a Maxakali strategy for interaction, just as it happens in the rituals between humans and spirits, tikmû̃ ũn e yãmĩy.

These two distinct approaches that the students and the teacher assume are a good example and reveal much about the differences between western logic and logic expressed by Amerindian peoples. Recognizing this brings up the reflection on the teaching of science in such a context. We started to take account of what would be necessary to establish another form of dialogue, a more robust listening. It would necessarily be an effort from both parties to recognize the existence of other viewpoints and, what's more, enable reflection starting from those other visions. We should think of science classes as a space for these relationships, for this exchange. This process brought upon reconsidering the relation between science and the world, students and ourselves and consequently repositioning ourselves before the very Maxakali people, or in other words, rethinking in turn the relationship that pervades the science classroom in these contexts.

\section{Discussion: Science Education as an Inventive Act and Space for the Construction of a Common World}

Through the course of this process, we began to realize that the same sensations of alienation that were felt when we were in an indigenous village, the Maxakali experience when they are in the city. The relationship, be it in the village or in an urban environment, is for both parties a constant anthropological exercise. The Maxakali interpret and interact within a world in a very different way than we do, and just as anthropologists act in relation to the indigenous peoples they study, they also constantly seek to comprehend the logic of the white people and to understand their mode of being and acting in their world. Identifying this was 
very significant.

As such, a course like the FIEI, that has the intention to be for indigenous educators to serve in villages and, especially, in science classes, can foster this reciprocal anthropological exercise. For this reason, it is necessary that our classrooms become spaces for a cosmopolitical ${ }^{1}$ practice, for the construction of a common world as proposed by Latour (2004). It is true that scientific knowledge and traditional knowledge draw upon a set of specific and profoundly distinct rules, procedures and forms of verification and transmission (Carneiro da Cunha, 2009) that, despite them never having been well understood, emerge in such a relationship. However, it is necessary to encourage that two modes of thinking coexist in a relation of equivalence that does not serve to waive away differences. Rather, it must be a symmetric relationship that abandons all forms of hierarchy, a space, at last, where all nationalities can coexist.

If we consider that the natural sciences are perhaps one of the principal expressions of western culture, our supposition is that the exercise of an indigenous person learning science is, to some extent, similar to the anthropology applied to understanding other cultures. If we take this as a premise, perhaps we can ask ourselves: how can we think of a science education that favors our indigenous students/anthropologists? Or rather, how can science classrooms become a truly pluricultural space in the sense of enabling the joint action of indigenous people and us professors as anthropologists?

Anthropology has as its central object of investigation culture or, as Wagner (2010: p. 27) suggests, "The phenomenon of man-the mind of man, his body, his evolution, origins, instruments, art or groups, are not simply in and of themselves, but rather are elements or aspects of a general standard or of a whole". The anthropologist seeks then to understand the culture they intend to study.

In Wagner's view (2010: p. 29) this process is only possible by starting from a common experience between the two parties, the anthropologist and the members of the other culture. To understand this other culture, it is necessary that the anthropologist integrate himself into that different form of life. In that way, the author affirms that to study another culture does not mean to analyze them objectively, but instead to relate with them. It means to establish a relationship between two varieties of the human phenomena, that which she studies and her own, with the purpose of generating understandings that can encompass the two.

Despite the differences and difficulties that have already been pointed to in the interactions with Maxakali students in the chemistry class, this reciprocal anthropological exercise was present the entire time. Independently of the objectives, a constant effort to understand the logic of Maxakali was demonstrated, and they sought to understand the logic of science. As such, the teacher began the class proposing that they speak about two related themes in the everyday life of the group, which also involved a knowledge of chemistry: the cultivation of a garden and the raising of fish. She considered the growth of living beings a ${ }^{1}$ Term coined by Stengers (1997). 
strong context to begin their conversation, insofar as, in that moment, it was an experience that they had in common. By contrast, they struggled to respond to her questions, which attempted to keep the conversation in the realm of science. They explained to the teacher that gardens were pioneered by the Maxakali teacher of the "Use of Territory", a course composed of a curricular level of indigenous schools in Minas Gerais. They demarcated a plot of land for this purpose, mixed cattle manure with the earth and spread around seeds of lettuce and other vegetables. They even recalled the great difficulty that they encountered in dealing with insects, the pests that attacked the plants. Afterwards, they spoke about their experience with pisciculture in Aldeia Verde. A large dyke was constructed for the fish. Periodically the fish were measured, and when some would have already reached a considerable size, they weren't eaten, so as to guarantee reproduction.

The students sought, the entire time, to float between the fundamentals of scientific knowledge and, further, to demonstrate themes of interest to them. Beyond the difficulties with pests in maintaining the garden, after explaining about the life of fish, they told the teacher that the biggest problem that the community faced in Aldeia Verde was the lack of potable water. The sole stream that ran through the Indigenous Land has inadequate water even for bathing. However, when the teacher spoke later about the necessity of nutritious food for children so that they could grow, and they were questioned about this, the debates about Maxakli cosmology came to light. The fundamentals of science, which they were trying to articulate until then, ceased to make sense in this new context and were abandoned.

On the other hand, when these new principles emerged, it was the teacher's turn to try to understand Maxakali logic. However, eventually, they stopped drawing connecting links between the two thoughts, which is why it was felt as extremely frustrating and the conversation was redirected to the discussion of nutrition and the growth of living beings, which brought them to resume scientific discourse, until it was concluded that all life needs food to grow.

To some extent, the difficulty they met in responding in the ambit of science such as when asked about how children grow is similar to the difficulty that was found in relating to the Maxakali viewpoint about the growth of children in chemical principles. In both cases, the reaction was to return to one's own logic. Finally, of the explanations that the Maxakali students presented, the teacher was unable to perceive any connection to scientific principles and this caused her to look towards her own actions and reevaluate them. The same thing seems to have happened with them. Whereas the teacher spoke about feeding fish, they maintained the discourse they had learned with the team that taught them about the nursery. However, when introduced to the idea of the growth of children, they could only see Maxakali cosmology and reshaped the conversation saying: my people speak like this, the Maxakali people speak like this [...].

This same sensation emerged in the final activity about boiling water. After many attempts to bring them to consider the presence of dissolved air in water, 
the teacher saw herself without many alternatives. The feeling was of utter defeat. As much as she would try, she couldn't find a way out. The only thing to do was to simply describe the scientific version of the phenomenon, an act totally out of line with her own behavior as a teacher.

As Wagner (2010: p. 34) affirms, when establishing such a relationship, it is inevitable that there will occur what the author calls culture shock. Until then, anthropologists are so imbedded in their own culture that it appears invisible. Immersion in this context in which two regimes of meanings and actions, those of the anthropologists and those of the native, are simultaneously experienced, brings consciousness of one's own culture. In this way, for the Maxakali, to study science helps them find solutions to the problems of water and concerning the gardens, but when they face a question so fundamental as the growth of children, they return directly to the Maxakali universe. As Wagner suggests, one's own culture becomes visible. The same thing happened with the teacher in the two discussions. After so many attacks on the thought of the other, she could only manage to look upon her own actions.

It is also interesting to observe how the idea that there is air dissolved in water had been constructed by the students. As it has been previously claimed, what constituted, for the Maxakali, the little bubbles that rose during the initial heating of the water is its own water vapor. For them, with heat, these bubbles grow until the vapor begins to release itself into the atmosphere. When in the final activity the teacher decided to explain the scientific view, they listened without questions, which intrigued her. She even considered the thought that they had not understood the idea or they simply they couldn't consider it as plausible.

In turn, the experience affected the teacher in various other moments during these classes, very often in activities with the Maxakali student of PIEI. However, after having recently reanalyzed the videos, it was possible to identify some of the teacher's faults in these moments. In another class, for example, a small grain of potassium permanganate, a pink salt, was added into a large bottle of water. The students were able to see the dissolution of the salt into the water with no agitation of the system. A Maxakli student then suggested that the "water air" is what had mixed the potassium permanganate in the water. In another moment, when discussing the behaviour of air within a syringe, speaking about the illustration made to represent their ideas, the same student suggested that the sea makes the sky and when I asked, attempting to comprehend his thought, she affirmed: Because, within the water, there is air, within the water, there is air [...].

Perhaps most surprising was to identify the relationships that the student made, the whole time, between scientific ideas with respect to water and air and the actions of the yãmĩy. The same student said: I have seen it as our spirit world. It is the same movement that she made in the discussion about the dissolution of potassium permanganate in water. When presented with the scientific idea that the materials, including water and potassium permanganate, are constituted by particles that move in empty space, she immediately affirmed that in Maxakali tradition, it's necessary to wake up the water before you drink it in the 
middle of the night.

All of these examples show us how it is impossible to construct any idea until you engage those that are already your own. Similarly, Wagner (2010: p. 30) claims the anthropological exercise of investigating the other has become, simultaneously, the investigation of one's self, insofar as one can only study the other by mobilizing one's own form of perception and being in the world. All of the student's attempts to explain scientific ideas brought her gaze back to herself, to the very way that the Maxakali people see and act on their surroundings. It is by starting from this movement that she will construct "a scientific idea" that unites the two forms of rationality, scientific and Maxakali.

It is true that her present conception of what water is and about how the air is dissolved in it is still very distant from that of science. What we intend to argue is that she or whoever else can only understand another form of rationality by starting from elements of their own culture. It is in this sense that, as Wagner (2010: p. 30) states, the "anthropologist 'invents' the culture that he believes he is studying" (emphasis added).

The notion of invention used by Wagner does not have the connotation of fancy, fantasy or fiction, as it is commonly given, but instead the productive imagination of the creative capacity (Goldman, 2011: p. 198). Wagnerian invention (Wagner, 2010: p. 36) is a process of objectification, which starts from observation and learning. A researcher will never comprehend the other culture as the native does. Her experience will always be carried by her own system of meanings, her own culture, which she has internalized. It will be through her capacity to produce meaning starting from her own culture that she will make meaning of the other's culture as well. However, for Wagner (2010: p. 36), what the researcher learns in the universe of the other will always be "an extension or superstructure, constructed around and with that s/he already knows" (emphasis added).

Invention is then understanding expressed by means of analogies generated by extensions from the personal notions of the researcher, transformed in relationship with the other culture. When identifying discrepancies between her ideas and the native culture, the researcher strives to redefine her analogies until she approximate more and more her own experience. So, processually the analogies will become more objective descriptions (Wagner, 2010: pp. 40-41). In this way, the ideas constructed by the Maxakali students, starting from the relationship between the two systems of thought, are very far from being definitive, well-polished constructions. The various experiences that they will experience or may experience, even in the universe of the non-indigenous and especially, in science classes, enable them to redefine their ideas, approximating science a little more each time.

This same process happened to the teacher as well over the course of these years. The ideas that she has today about Maxakali cosmology are very distinct from those that she had in the past. The innumerable moments of coexistence in the village, in her house, in the university and the many writings of different re- 
search have, gradually, brought her to describe and reconstruct a description of the Maxakali universe uncountable times. But beyond that, this experience has brought her to reflect on her own comportment as a teacher, which also has echoes with the Wagnerian theory.

Once engaged in two cultures at the same time, the creation of another world considers the unique regime of signification and, consequentially, the researcher will experiment in transforming their own culture. Attempting to understand another culture, the anthropologist will be implicated in a process of an "introspective understanding of one's own operations and capabilities" (Wagner, 2010: p. 45), which brings about the process of self-knowledge, reflection on one's own culture. In the author's words:

"In experiencing a new culture, the researcher identifies new potentialities and possibilities to live life, and can effectively bring oneself through a change in personality. The studied culture becomes 'visible' and subsequently 'plausible' to him/her; in the beginning s/he considers it a distant entity, a way of doing things, and after as a way according to which s/he could do things" (Wagner, 2010: p. 30-31).

If culture is creative and we all have culture, Wagner concludes, that it is not only the culture of the anthropologist but the studied culture and all others, which possess that creative capacity, or in other words, the native also invents the culture of the anthropologist and her own. We are all native and anthropologists. Therefore, all exercises in meaning are, in their conception, an inventive exercise.

\section{Conclusion}

Roy Wagner is an anthropologist and not an educator. His concern is with the thought and practice of ethnography and the meaning of its object, which is culture. However, perhaps a parallel can be traced between what he calls the understanding of other human phenomena and the science education in a pluricultural context. In other words, perhaps we can think of science education as part of a struggle to comprehend the culture of the other, as an anthropological exercise in Wagnerian terms.

We start then, as the author, from the premise that it is only possible to comprehend the other by mobilizing one's own way of perceiving and acting in the world. Embedded in their culture, the indigenous students will only be able to access scientific knowledge starting from their own terms. Only via the meanings that are essential to them, can they create analogies and redefine them in ways that approximate, little by little, the scientific principles of a question. This places us before the challenge of turning the science classroom into a space for such a creative exercise.

On the other hand, if what is sought is the construction of a common world, a practice of a cosmopolitical nature, in Latourian terms, this relationship necessarily reveals a two-way street. Teachers are also apprentices of the culture of their student and invent starting from their own terms. The science classroom in 
a pluricultural context appears to us then a fecund place to foster common experiences amongst diverse forms of rationality, a reciprocal anthropological exercise, the indigenous student that seeks scientific knowledge and the professor that seeks traditional knowledge.

The proposition of a science lesson as an invention of meaning in the sense given by Wagner appears to us a path to build a cosmopolitical space, as Latour suggests. The idea is to promote this encounter, this coexistence between different forms of meaning, but without the pretense of bringing indigenous students to cross the frontiers that separate the two views (Aikenhead, 2009), so that then they can exercise a new form of rationality, science (Gasché, 2004).

The goal is not a way of helping students to use another rationality. It is to admit that we all have our own forms of meaning and being in the world and that, clearly, we can understand other ways of doing this, yet we can never do as the members of another culture. All understanding that we construct, be it associated with our own universe or the other, will always be laden with our own logic. In this form, the goal is striving for relationship, for common experience, that fosters the invention, in Wagnerian terms of another rationality.

It is fundamental that we also recognize that the questions that one presents to some are completely different than those that instigate others. This is apparent in the examples that have been described of the teacher's interactions with the Maxakali students. In trying to relate the process of feeding with the growth of living things, she dragged in the background crucial questions for chemistry like the constitution and modes of material interactions. For the Maxakali students, what was essential was the interaction with the yãmĩy, to understand how this interaction happens, and how it interferes and constitutes life itself.

As such, resorting to a context that gives meaning to the scientific concepts that we wanted to approach as the motivator of discussion still seems to be a strong strategy. However, the discussion should be conducted in a manner that facilitates that the results affect both parties and, furthermore, that it brings us, both students and teachers, to listen to ourselves, recognizing one's own form of knowledge, and then begin the process of invention of other ideas. Listening to one's own questions, for then one can (re)invent the questions of the other.

Returning to the village and exercising one's office as teacher, the indigenous teacher, now engaged in two cultures at the same time, will be the link between two worlds. Just as the anthropologist reveals the studied culture to their peers by means of ethnography (Wagner, 2010: p. 30), the indigenous teacher will assume the function of a translator of the western universe for his people. Fostering that our indigenous students exercise their inventive, creative capacities, effectively contributes to an amplification of their capacities of self-determination, not only for themselves, but also for their people.

\section{References}

Aikenhead, G. S. (2009). Educação científica para todos. Portugal: Ed. Pedago.

Álvares, M. M. (2012). Criança e transformação: os processos de construção de 
conhecimento. In: Tassinari, A. M. I., Grando, B. S., \& Albuquerque, M. A. S. (Eds.), Educação Indígenas: reflexões sobre noçôes nativas de infância, aprendizagem e escolarização (pp. 79-91). Florianópolis: Ed. da UFSC.

Brasil. Presidência da República. Casa Civil (1988). Constituição da República Federativa do Brasil de 1988.

http://www.senado.gov.br/legislacao/const/con1988/CON1988_13.07.2010/CON1988.s $\underline{\mathrm{htm}}$

Carneiro da Cunha, M. M. (2009). Relações e dissensões entre saberes tradicionais e saber científico. In: Cultura com Aspas e outros ensaios (pp. 301-310). São Paulo: Editora Cosac Naify.

Driver, R., Asoko, H., Leach, J., Mortimer, E., \& Scott, P. (1999). Construindo o conhecimento científico na sala de aula. Química Nova na Escola, 9, 31-40.

Dutra, M. V., Rezende, Z., Resende, M. M. S., Mattos, K. G., Almeida, M. I., Álvares, M. M., \& Romanelli, L. I. (2003). Krenak, Maxakali, Pataxó e Xakriabá: a formação de professores indígenas em Minas Gerais. Em Aberto, 20, 7-11.

Gasché, J. (2004). Niños, maestros, comuneros y escritos antropológicos como fuentes de contenidos indígenas escolares y la actividad como punto de partida de los procesos pedagógicos interculturales: Un modelo sintáctico de cultura. Mexico: Educando en la diversidad.

Goldman, M. (2011). O fim da antropologia. Novos Estudos-CEPBRAP (pp. 34, 89, 195-211). São Paulo: Ed.

Latour, B. (2004). Políticas da natureza: Como fazer ciência na democracia. Translation Carlos Aurélio Mota de Souza. Bauru: Editora EDUSC.

Maxakali, R. et al. (2008). Hitupmã’ax: Curar. Belo Horizonte: Cipó Voador.

Mortimer, E. F., \& Machado, A. H. (2003a). Química para o Ensino Médio-Assessoria Pedagógica. São Paulo: Editora Scipione.

Mortimer, E. F., \& Scott, P. H. (2003b). Meaning Making in Secondary Science Classrooms. Maidenhaid: Open University Press.

Stengers, I. (1997). Cosmopolitiques. Paris: La Decouverte/Les Empecheurs de penser en rond, 1. 1: La Guerre des sciences.

Wagner, R. (2010). A invenção da cultura. Translation Marcela Coelho de Souza e Alexandre Morales. São Paulo: Cosac Naify.

Scientific Research Publishing

\section{Submit or recommend next manuscript to SCIRP and we will provide best service for you:}

Accepting pre-submission inquiries through Email, Facebook, LinkedIn, Twitter, etc. A wide selection of journals (inclusive of 9 subjects, more than 200 journals)

Providing 24-hour high-quality service

User-friendly online submission system

Fair and swift peer-review system

Efficient typesetting and proofreading procedure

Display of the result of downloads and visits, as well as the number of cited articles

Maximum dissemination of your research work

Submit your manuscript at: http://papersubmission.scirp.org/

Or contact ce@scirp.org 